\title{
A SURVEY OF STATISTICS OF BUILDING FIRES IN LATVIA
}

\section{*Edvins Grants}

Latvia University of Life Sciences and Technologies, Latvia

*Corresponding author's email: edvins.grants@e-koks.lv

\begin{abstract}
A survey of 8985 records on all fires in Latvia in 2019 gathered by State Fire and Rescue Service was performed to find out if gathered data is suitable and complete for establishment of statistical database for fire protection engineering. The purpose of the survey is to assess suitability of provided content for further studies of the characteristic building fire occurrence probabilities in different building occupancy classes and to obtain solid background for calculations of national values of fire activation partial safety factors which could be implemented in national annex of Eurocode 1 part 1-2. Study contains data about the total number of building fires with relevance to their occupancy types and review of recorded fire causes for residential buildings that provide overall insight on typical causes of fires in dwellings.
\end{abstract}

Key words: fire protection engineering, fire statistics, fire causes, building occupancy class.

\section{Introduction}

Latvia is an Eastern European country which after regaining its independence from the Soviet Union is undergoing constant changes continues to develop and wants to reach the level of welfare equal to its Western European neighbours. With the resources available nation is working to achieve an equivalent, if not a better level of protection of people in their day-to-day lives where a significant improvement can be achieved by improving fire safety and protection levels of buildings and structures. Fire safety of buildings and structures is one of the indicators that indirectly provides information about the state of the surrounding environment and infrastructure - whether safety goals for buildings are achieved and whether the implemented protection measures improve the existing situation. Unfortunately, the compiled statistics (Brushlinsky et al., 2019) on the total number of fires and the total number of deaths in Latvia over the period 1992-2017 are not flattering. The data collected so far show that the total number of fires in the country (Figure 1) have a tendency to fluctuate (State Fire and Rescue Service, 2020). Since 2014 the total number of fires has decreased but has not reached the lower point recorded at the beginning of the period under consideration. It means that the total number of fires have maintained tendency to increase. Latvia has one of the highest annual and average number of fire deaths per 100,000 inhabitants among the member states of the European Union (Brushlinsky et al., 2019).

In Cabinet of Ministers Order No. 7 (Cabinet of Ministers, 2019) and the State Audit Office's audit report (Latvia State Audit Office, 2016) are conclusions that the measures taken by State Fire and Rescue Services (VUGD) so far are not sufficiently effective. Taken measures are too general and strategic data collected to determine the effectiveness of the civil protection measures taken is too general and therefore aimless.

The importance of fire statistics is also highlighted by the Society of Fire Protection Engineers (Hall \& Joglar, 2016), which provides a review of the main data analysis methods and references to the most significant studies to date. According to the Implementation of Eurocodes Handbook 5 (Schleich, 2005) the calculation methods presented in Eurocode 1 Part 1-2 (Latvian Standard, 2013) for determination of fire load densities and related partial safety factors are based on studies of building fire statistics (Fontana, Favre, \& Fetz, 1999). However, conclusions and results found in aforementioned studies (Fontana,

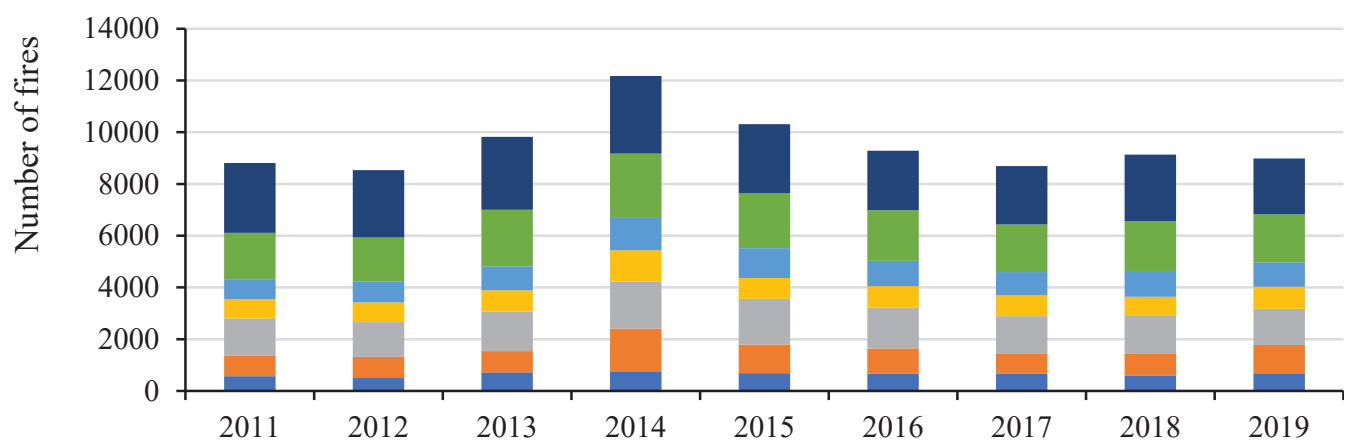

Figure 1. Annual number of fires in regions and largest cities of Latvia, (2011-2019)

(State Fire and Rescue Service, 2020). 
Favre, \& Fetz, 1999) should be interpreted with caution when considering their applicability to the Latvian situation as the studies have been conducted on the situation in Switzerland where affecting factors such as administrative system and level of welfare differ. This is evidenced by the fact that the experience of mandatory insurance of buildings in Switzerland has already accumulated over 200 years (Fontana, Favre, \& Fetz, 1999) whereas in Latvia mandatory insurance against fire and acts of God (natural disasters) is not yet practiced.

In this study, limited access dataset about registered fires in Latvia in 2019 provided by the State Fire and Rescue Service (VUGD) were evaluated. Forest fires are excluded.

The purpose of the survey is to assess provided content in the data collected by the VUGD and its relevance for further studies of the characteristic building fire occurrence probabilities in different building occupancy classes to provide engineering data for building fire protection engineers.

\section{Materials and Methods}

The research was conducted in several successive stages. In first stage analysis of relevant literature and regulatory documents were performed and organizations that collect data about building fires in Latvia were identified. In the next stage after evaluation of obtained public fire statistics (Brushlinsky et al., 2019; State Fire and Rescue Service, 2020) and receiving data sets from VUGD (8985 recorded fires in 2019 in Latvia) information gap analysis was performed. In addition, data from the Ministry of Environmental Protection and Regional Development of the Republic of Latvia (VARAM) about the administrative territorial divisions of Latvia and their areas (Ministry of Environmental Protection and Regional Development of the Republic of Latvia, 2020) and publicly available data about population in 2019 were obtained (Central Statistical Bureau of Latvia, 2020).

At the third stage an in-depth analysis of the fire data was carried out during which the data grouping was performed by separating the building fires from other fires. Number of building fires were compared between regions of Latvia by taking in-to account population in each of the territories. Comparison of data was based on dispersion analysis. The descriptive statistics were performed using computer software ' $\mathrm{R}$ v. 3.6.2.' but results are presented using tables, graphs and maps created using 'iMapBuilder Online v11.064'.

\section{Results and Discussion}

Survey of publicly available fire statistics

The only public source of information on registered fires in Latvia are data summaries provided by VUGD which are available as annual reports 'Rescue, fires and their consequences' (State Fire and Rescue Service, 2020) and annual 'Public activity reports' (State Fire and Rescue Service, 2019). An additional source of information about fires in Latvia is data gathered by 'International Association of Fire and Rescue Services' (CTIF - Comité Technique International de prevention et d'extinction de Feu), whose member state is Latvia (Brushlinsky et al., 2019).

It must be mentioned that interesting data collection is presented by University of Oxford - 'Our World in Data' (Metrics and Evaluation IHME, 2018). In this data collection are reviews about main causes of death including fires worldwide.

Open access information data collections show that they deal with fires and their consequences in general, without distinguishing building fires from other fire types. Such information does not provide accurate clues about the actual fire hazards in buildings and the likelihood of a fire occurrence. The structure of the content of the available statistics is presented in Table 1 .

Data sources provide a general insight into:

- the number of fires in different administrative territories of the state without information how they are related to types of fires;

- the number of people injured and killed in fires in a country without relevance to the types of fires or their causes;

- distribution of the total number of fires by type without relevance to the administrative territories;

- distribution of total number of fires by type of cause, without linking it to fatalities or types of fire.

\section{Analysis of data of building fires}

According to the Law on Administrative Territories and Populated Areas (The Parliament of the Republic of Latvia, 2008), Latvia is currently divided into 119 administrative territories - 110 Municipalities and 9 cities, including Riga the capital of the country. For general overview of distribution of fire gradation of the number of fires by population density for each municipality of Latvia was established. Simplified summary on population density in administrative territories of Latvia in the beginning of 2019 is demonstrated in Figure 2.

The highest population densities are in the cities where average population density is $1100( \pm 366.572$, $\alpha=0.05$ ) citizens per $\mathrm{km}^{2}$ and municipalities around the capital city Riga where population density tends to be higher than 60 citizens per $\mathrm{km}^{2}$, but it is not higher than 210 citizens per $\mathrm{km}^{2}$ (Figure 2). In other parts of Latvia population density is low - below 30 citizens per $\mathrm{km}^{2}$ with exceptions of Cesis and Aizkraukle municipalities. Population density in Riga capital city of Latvia is above 2000 citizens per $\mathrm{km}^{2}$. For 


\section{Data availability in open access data sources}

\begin{tabular}{|c|c|c|c|c|}
\hline Information Type & DS $1 *$ & DS $2 * *$ & DS $3 * * *$ & $\operatorname{DS} 4 * * * *$ \\
\hline Total number of fires & $\checkmark$ & $\checkmark$ & $\checkmark$ & $x$ \\
\hline Number of fires in administrative territories of Latvia & $\checkmark$ & $\checkmark$ & $x$ & $x$ \\
\hline Type of accident & $\checkmark$ & $\checkmark$ & $\checkmark$ & $x$ \\
\hline Number of injuries and fatalities & $\checkmark$ & $\checkmark$ & $\checkmark$ & $\checkmark * * * * *$ \\
\hline Assumed reason of fire incident & $x$ & $\checkmark$ & $x$ & $x$ \\
\hline Number of rescue services performed other than firefighting & $\checkmark$ & $\checkmark$ & $x$ & $x$ \\
\hline Type of fire service calls & $x$ & $\checkmark$ & $\checkmark$ & $x$ \\
\hline Number of fire safety control in buildings & $x$ & $\checkmark$ & $x$ & $x$ \\
\hline Number of injured firefighters & $x$ & $x$ & $\checkmark$ & $x$ \\
\hline Comparison of firefighting equipment & $x$ & $x$ & $\checkmark$ & $x$ \\
\hline Fire service personnel by gender & $x$ & $x$ & $\checkmark$ & $x$ \\
\hline
\end{tabular}

$\checkmark \quad$ Information available in the data collection

$x \quad$ Information not available in the data collection

* $\quad$ DS 1 - State Fire and Rescue Service annual reports 'Rescue, fires and their consequences'(State Fire and Rescue Service, 2020)

** DS 2 - State Fire and Rescue Service annual 'Public activity reports'(State Fire and Rescue Service, 2019)

*** DS 3 - CTIF annual reports (Brushlinsky et al., 2019)

**** DS 4 - University of Oxford data collection - 'Our World in Data' (Metrics and Evaluation IHME, 2018)

***** Data collection provides information about death rates only

comparison of municipalities, administrative territories of Latvia are usually grouped in larger regions called Regions of planning or Statistical regions.

Looking at the distribution of building fires graded by population density classes and regions (Figure 3 ), it can be seen that the largest number of fires appears in regions with the highest population densities and in the territories with lowest population density. Increased number of fires in territories with low population density can be explained with the fact that territory within this population class covers the largest part of the country. Largest number of building fires per 1000 inhabitants is in large cities of republic (Figure 4); however, it seems to be proportional with the density

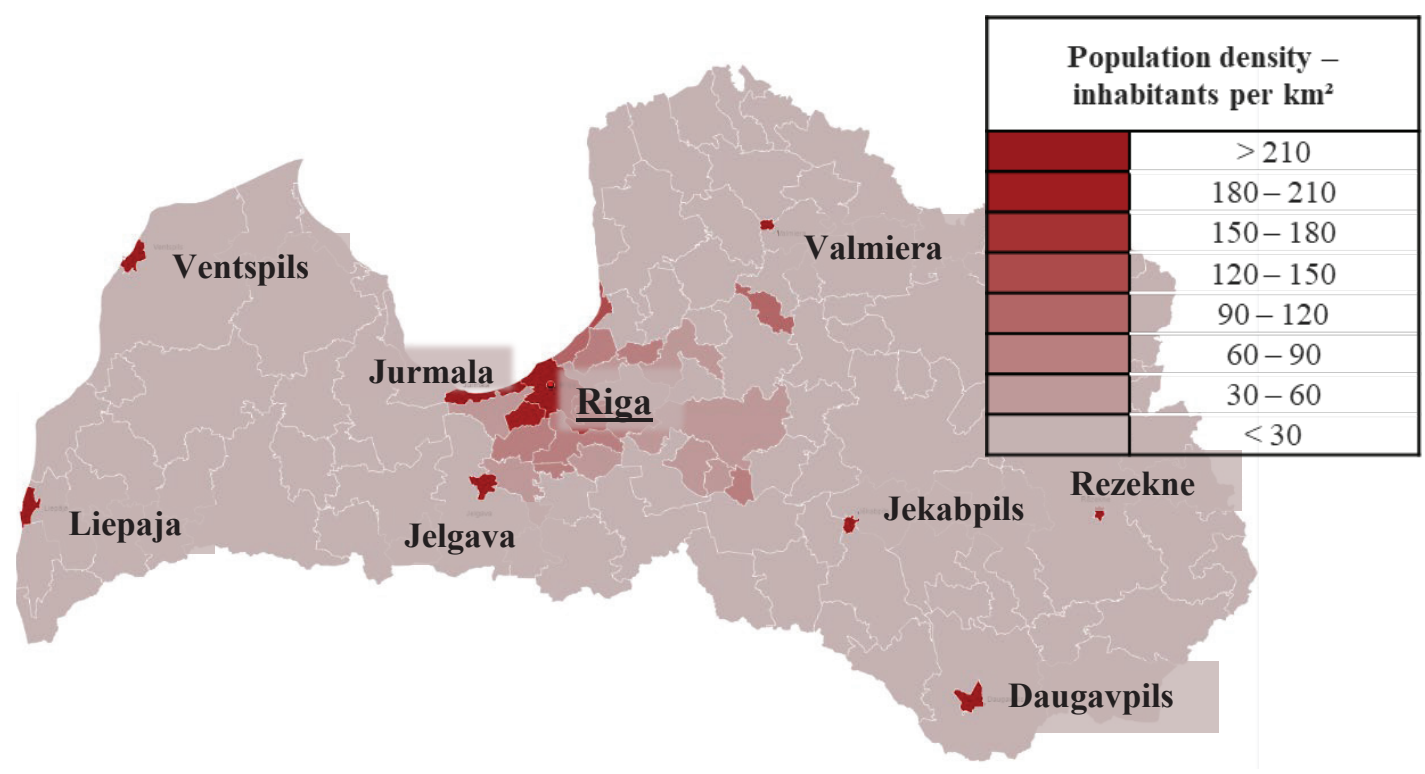

Figure 2. Characteristic population density in administrative territories of Latvia. 


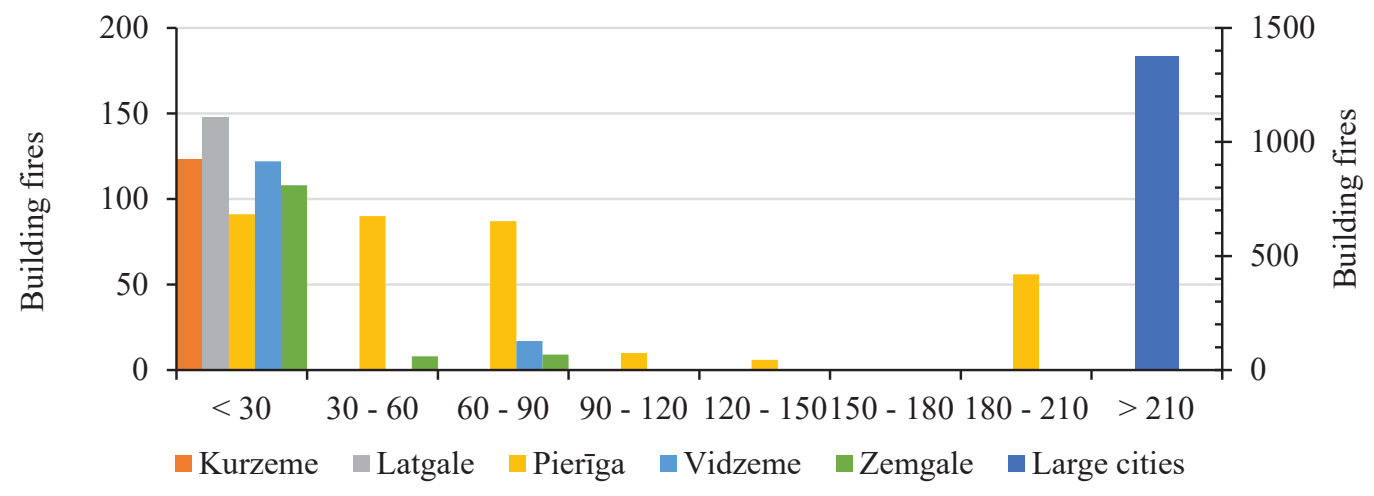

Figure 3. Building fires by population density in regions of Latvia in 2019.

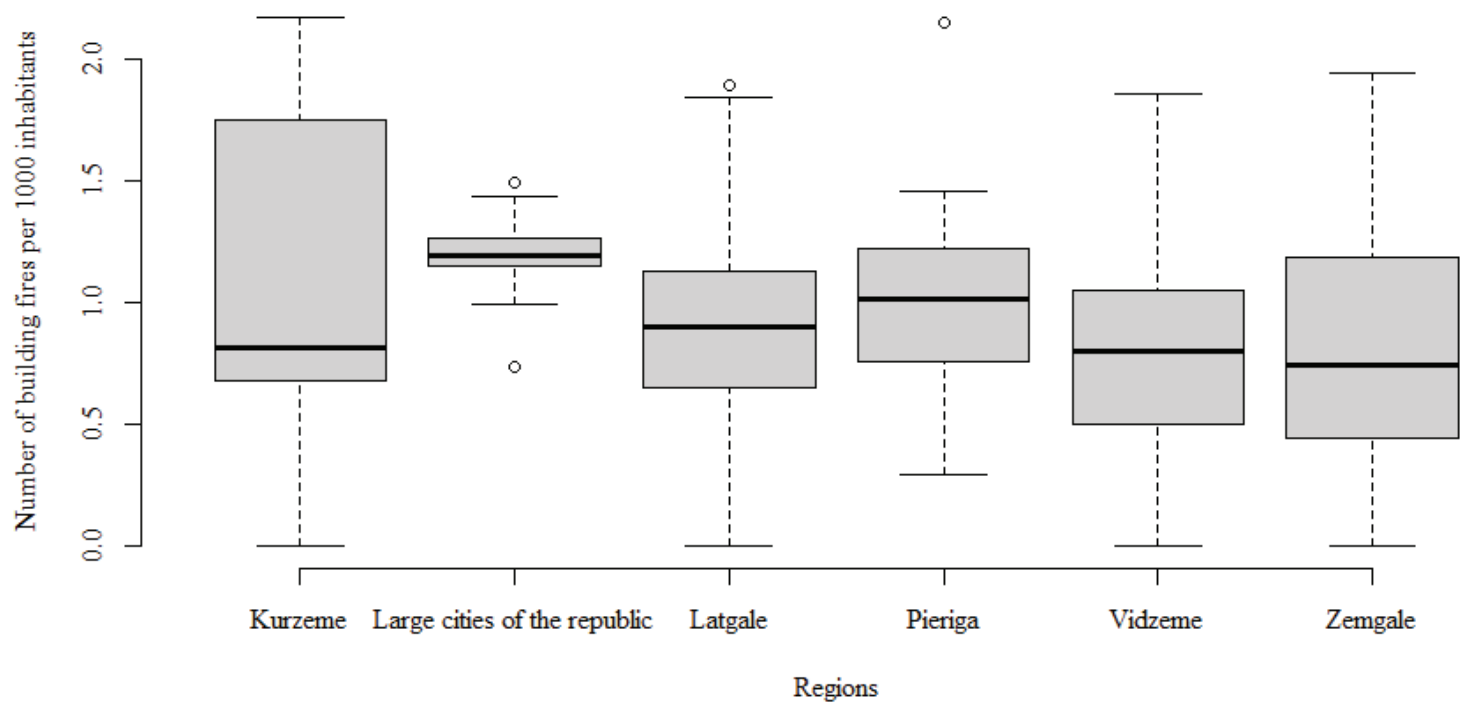

Figure 4. Number of building fire per 1000 inhabitants in regions of Latvia. Median (middle black line), confidence region (grey box), maximum and minimum values within range of 1,5 times confidence region (dashed lines), outliers (dots).

of population because by comparing dispersions of building fires per 1000 inhabitants (Figure 4) of each municipality, it is found that there is no significant difference in number of building fires among regions of Latvia $(\mathrm{p}>0.05)$.

Informative background (Schleich, 2005) for theoretical basis of Eurocode 1 part $1-2$ (Latvian Standard, 2013) describe important studies (Fontana, Favre, \& Fetz, 1999) of building fires where data was obtained by surveying insurance companies providing mandatory building insurance services in cantons of Switzerland and therefore data is comprehensive, because it covers all buildings in the country. Data also include cases in which fire and rescue services were not called because the amount of fire was negligible or self-extinguished but an insurance claim was initiated. The situation in Latvia is different. Neither VUGD nor the insurance companies in Latvia carry out comprehensive inventory and gradation of all buildings in the country. So the collection of data about building fires that would be equivalent to data mentioned in current studies (Fontana, Favre, \& Fetz, 1999) might prove to be a challenging task. In the light of the information above contacts have been established with the responsible officers for data management and gathering from operational reports in VUGD and a mutual cooperation agreement has been concluded. Within the framework of the agreement an expanded information database on fires in Latvia in 2019 was obtained for research purposes where sensitive information had to be protected and handled with care. At the same time other cooperation has been initiated with some of the national insurance companies and will be expanded in future. Further in this paper the results obtained from the data received from VUGD will be presented.

The relevant fire database does not contain information about fatalities, so it is not possible to link specific building occupancy classes and causes of fire to the number of casualties. To assess building fires 


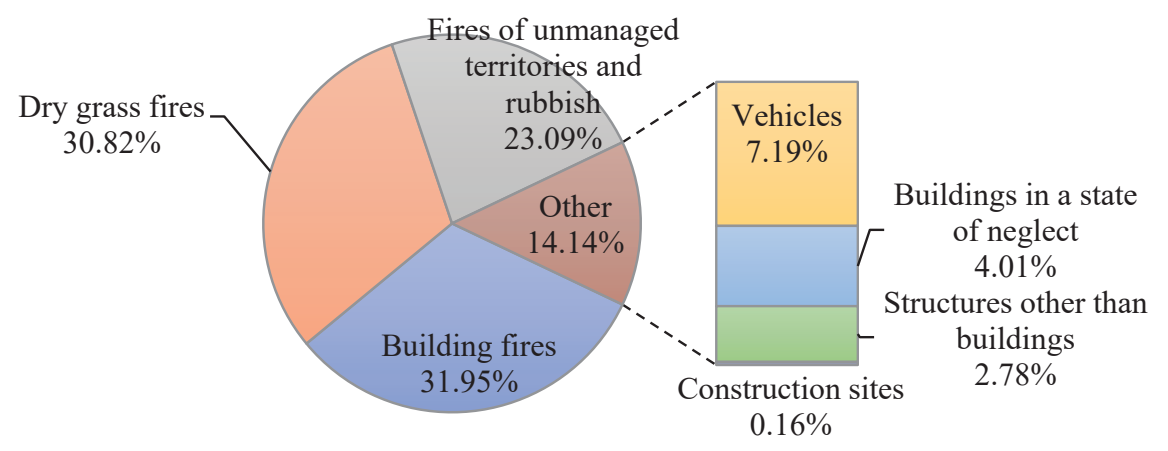

Figure 5. Distribution of recorded fires by fire origin.

operational information about all recorded 8985 fire accidents in Latvia in 2019 was reviewed. To present distribution of fires by fire origin with relevance to the occupancy of the place under fire all on the basis of operational records all cases were sorted into groups of fire origin as presented in Figure 5. Classification is slightly different from already used classification in data tables because there were encountered some inconsistencies. For example: there are cases when garage premises are classified either as non-residential premises or transport buildings. Inconsistencies encountered also with structures such as poles for electricity land lines, where, for example, if the pole is built in the territory where manufacturing facilities are, then it is classified as fire in manufacturing facility etc. According to this data review of total number of fires in Latvia is distributed in seven main groups Building fires (31.95\%), Dry grass fires (30.82\%), Fires of unmanaged territories and waist (23.09\%), Vehicle fires (7.19\%), Buildings in a state of neglect $(4.01 \%)$, structures $(2.78 \%)$ and construction sites $(0.16 \%)$.

Data grouping revealed that the previous classification of fires by fire origins (State Fire and Rescue Service, 2020) is based on the terminology and definitions given in Regulation No. 238 - Fire
Safety Regulations (Cabinet of Ministers, 2016) where number of definitions for fire origins is smaller than number used and necessary for data classification in practice. Also, in practice used fire origin classification has caused problems for VUGD officers to grade fire origin in special cases when fire occurs in first floor commercial premises of nine storey residential building. Afore mentioned and similar cases are causing difficulties for fire protection engineers, structural engineers and architects as well when adequate fire protection level has to be established with relevant fire protection measures. The fact that fire fighters and building engineers have to use regulations with inconsistent classifications for building occupancies is not helpful either. For example, national Regulations No. 333 - LBN 201-15 (Cabinet of Ministers, 2015), No. 238 - Fire Safety Regulations (Cabinet of Ministers, 2016) and LVS EN 1991 - 1 - 2 (Latvian Standard, 2013) each have their own classifications for building occupancies. This situation makes room for interpretations that can cause errors in building designs. To solve this situation further studies about possible solutions how to harmonise different classifications of the same purpose between national regulations and European standards might prove useful.

\section{Distribution of building fires by occupancy types defined in LBN 201-15}

\begin{tabular}{|l|l|c|}
\hline \multicolumn{2}{|c|}{ Building occupancy types according LBN 201-15 (Cabinet of Ministers, 2015) } & $\begin{array}{c}\text { Distribution of } \\
\text { building fires, \% }\end{array}$ \\
\hline Type I & Dwellings and residential buildings & 84.01 \\
\hline Type II & Accommodation buildings - hotels, hostels etc. & 0.62 \\
\hline Type III & Hospitals, prisons or other similar establishments & 0.58 \\
\hline Type IV & Public buildings for commercial purposes and places of assembly & 4.66 \\
\hline Type IVa & Education buildings and kindergartens & 0.31 \\
\hline Type V & Administrative buildings and office buildings & 1.69 \\
\hline Type VI & Industrial buildings and storages & 6.08 \\
\hline Type VIa & Rural production buildings and structures & 1.64 \\
\hline Type VII & Garages and similar buildings & 0.41 \\
\hline
\end{tabular}




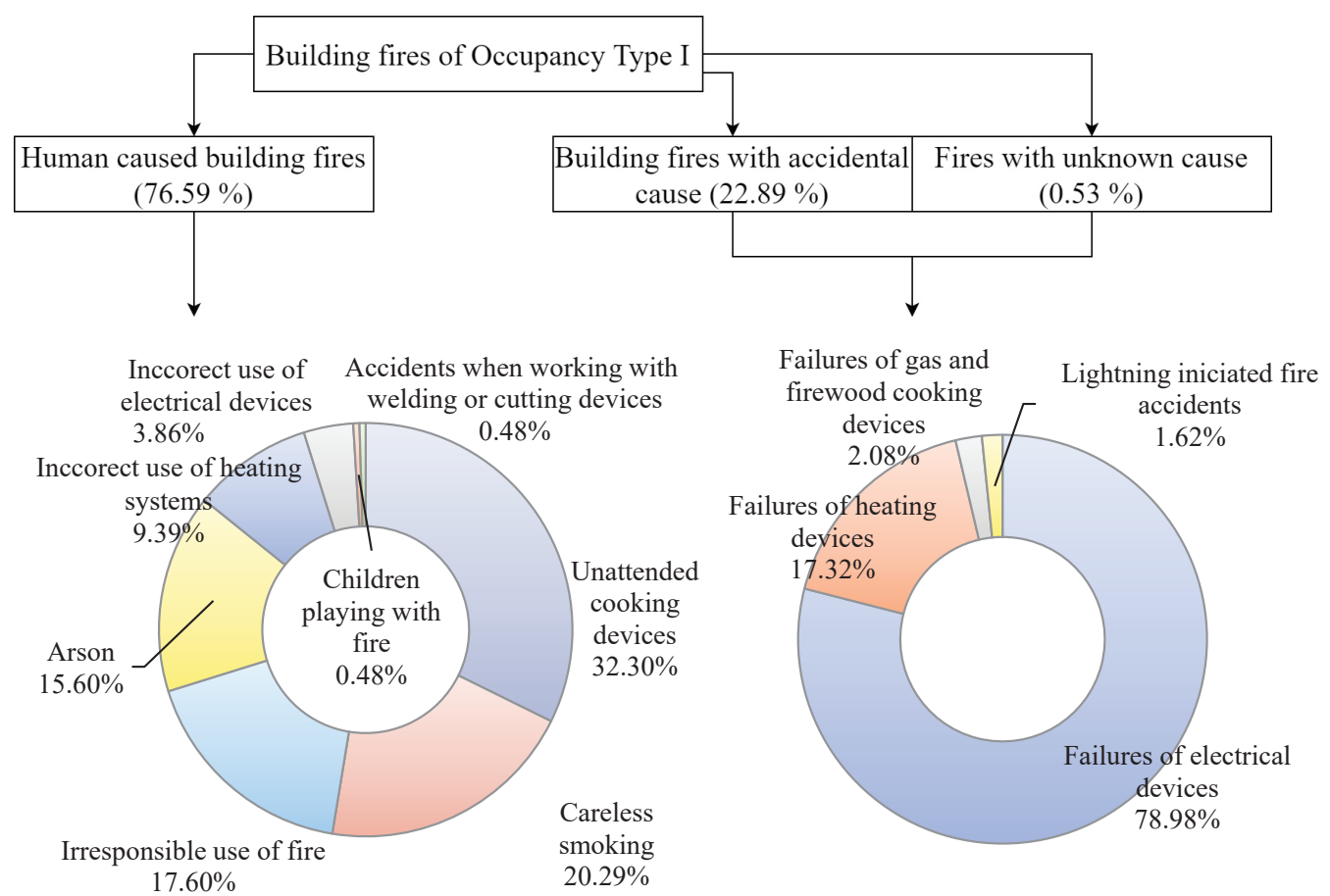

Figure 6. Distribution of Occupancy type I building fires by nature of reasons causing fire and assumed causes.

Table 2 demonstrates how building fires are distributed between different occupancy types if data are grouped according to Cabinet of Ministers Regulation No. 333 (Cabinet of Ministers, 2015) instead of Cabinet of Ministers Regulation No. 238 (Cabinet of Ministers, 2016).

Largest part of recorded building fires (84.01\%) in Latvia in 2019 can be classified as residential building fires. Number of building fires of other occupancy types are significantly smaller. For occupancy type I building fires most common reasons causing fire can be divided into three groups (Figure 6) where fires caused by human actions take first place with $76.59 \%$ but accidents without human interventions cover only $22.89 \%$ of recorded cases. Interestingly, among fire accidents caused by human, largest part of records comprises of cases where a fire accident happened because of unattended cooking devices (32.30\%), careless smoking (20.29\%) and irresponsible use of fire or open flame $(17.6 \%)$. In order to determine the probability of a fire occurring for any of occupancy type buildings the total number of buildings in the country grouped by occupancy types should be known. Information about number of buildings in the country where all existing buildings would be grouped by occupancy according to LBN 201-15 were not available yet.

\section{Conclusions}

1. The data obtained so far are inadequate to develop detailed conclusions about the causes of the fires and to determine the probabilities of building fires for each of the occupancy type, since the data were not comprehensive and did not include the total number of buildings in the country for each occupancy type.

2. There are inconsistencies and differences in the classification of buildings according to their occupancy type, not only between national regulations in the fields of firefighting and building design, but also between Latvian and European regulations. This situation should be improved in order to simplify the work with engineering data and to develop a common understanding of building fires and design at national level among related industries and harmonise it with European level.

3. Comparing the administrative territories of Latvia by the number of fires, it was found out that the number of building fires is proportional to the population of the respective territories. There is no significant difference between the regions of Latvia in the number of building fires per 1000 inhabitants. This finding aligns with the distribution of fire by nature of fire cause for residential buildings where it was found that largest part of residential fires is caused by careless human actions.

4. There is a lot of information and records gathered about building fires in Latvia through past years; however, not all of the data can be used for fire protection and structural engineering. This study provides first insight in current situation and gives hints about data necessary to be gathered in 
future studies to help fire engineers by providing useful engineering data.

\section{Acknowledgement}

This study was supported by Forest Sector Competence Centre of Latvia within framework of research project - 1.2.1.1/18/A/004 - P1. Special gratitude shall be expressed to State Fire and Rescue Service for support with data and useful recommendations.

\section{References}

Brushlinsky, N., Ahrens, M., Sokolov, S., \& Wagner, P. (2019). World Fire Statistics, Report No. 24 (p. 64). CTIF, International Association of Fire and Rescue Services, National committees CTIF of Russia, Germany, USA.

Cabinet of Ministers. (2015). Ministru kabineta noteikumi Nr. 333 par Latvijas büvnormatīvu LBN 201-15 'Būvju ugunsdrošība' (Cabinet Regulation No. 333 Regarding Latvian Building Code LBN 201-15 'Fire Safety of Structures'). Latvijas Vēstnesis, 30.06.2015., 125(5443), Cabinet of Ministers. Retrieved March 3, 2020, from https://likumi.lv/ta/id/275006-noteikumi-par-latvijas-buvnormativu-lbn-201-15-buvjuugunsdrosiba. (in Latvian).

Cabinet of Ministers. (2016). Ministru kabineta noteikumi Nr. 238, Ugunsdrošǐbas noteikumi (Cabinet Regulation No. 238, Fire Safety Regulations). Latvijas Vēstnesis, 78(5650), 22.04.2016. Cabinet of ministers. Retrieved on March 5, 2020, from https://likumi.lv/ta/id/281646-ugunsdrosibas-noteikumi. (in Latvian).

Cabinet of Ministers. (2019). Ministru kabineta rīkojums Nr. 7, Konceptuālais ziņojums 'Par valsts politiku ugunsdrošǐbas jomā' (Cabinet Order No. 7, Principal Report 'On State Policies in Field of Fire Safety'). Latvijas Vēstnesis, 11.01.2019. No. 8(6347). Cabinet of Ministers. Retrieved March 4, 2020, from https:// likumi.lv/ta/id/304174-par-konceptualo-zinojumu-par-valsts-politiku-ugunsdrosibas-joma. (in Latvian).

Central Statistical Bureau of Latvia. (2020). ISG020. Population number and its change by statistical region, city, town and county. Retreived March 3, 2020, from http://data1.csb.gov.lv/pxweb/lv/iedz/iedz iedzskaits_ikgad/ISG020.px/table/tableViewLayout1/.

Fontana, M., Favre, J.P., \& Fetz, C. (1999). A survey of 40,000 building fires in Switzerland. Fire Safety Journal, 32(2), 137-158. DOI: 10.1016/S0379-7112(98)00034-4.

Hall, J.R.J., \& Joglar, F. (2016). Probability and Statistics. In SFPE Handbook of Fire Protection Engineering (5 $5^{\text {th }}$ Edition, pp. 2827-2874). Springer New York. DOI: 10.1007/978-1-4939-2565-0_73.

Latvia State Audit Office. (2016). Audita ziņojums Nr. 2.4. 1-9/2015. 'Vai valstī īstenotie ugunsdrošības pasākumi ir pietiekami?' (Audit report No. 2.4. 1-9/2015. 'Are Fire Safety Measures Established Sufficient?') (p. 87). Riga, Latvia State Audit Office (Report No. 2.4.1-9/2015). (in Latvian).

Latvian Standard. (2013). LVS EN 1991-1-2:2003/AC:2013. Eurocode 1: Actions on structures - Part 1-2: General actions - Actions on structures exposed to fire, (p. 59). CEN/TC 250, Brussels.

Metrics and Evaluation IHME. (2018). Global Burden of Disease Collaborative Network. Global Burden of Disease Study 2017 (GBD 2017). Results. Metrics and Evaluation IHME; Seattle, United States: Institute for Health, Retrieved March 5, 2020, from https://ourworldindata.org/grapher/fire-death-rates.

Ministry of Environmental Protection and Regional Development of the Republic of Latvia. (2020). Information about municipalities in Latvia. Retrieved March 4, 2020, from http://www.varam.gov.lv/lat/darbibas veidi/pasv/. (in Latvian).

Schleich, J.-B. (2005). Chapter III - Calibration of Reliability Parametres. In Implementation of Eurocodes, Handbook 5, Design Of Buildings For The Fire Situation (pp. III-1-III-30). Leonardo da Vinci Pilot Project CZ/02/B/F/PP-134007, retrieved March 3, 2020, from https://eurocodes.jrc.ec.europa.eu/showpublication. php?id $=66$.

State Fire and Rescue Service. (2019). Valsts ugunsdzēsības un glābšanas dienesta publiskie pārskati no 2010.-2018. gadam (Open Access Reports on Annual Activities of State Fire and Rescue Service From 2010-2018). Retrieved March 5, 2020, from. https://www.vugd.gov.lv/lat/aktualitates/publikacijas/gada publiskie_parskati. (in Latvian).

State Fire and Rescue Service. (2020). Pārskati par ugunsgrēkiem un to radītajām sekām no 2011.-2019. gadam (Reports About Fires And Their Consequences From 2011-2019). (p. 23). Retrieved March 4, 2020, from https://www.vugd.gov.lv/lat/aktualitates/statistika. (in Latvian).

The Parliament of the Republic of Latvia. (2008). Administratīvo teritoriju un apdzīvoto vietu likums (Law On Administrative Territories and Populated Areas). In Latvijas Véstnesis No. 202, 30.12.2008. Retreived March 6, 2020, from https://likumi.lv/ta/en/en/id/185993-law-on-administrative-territories-and-populatedareas. (in Latvian). 